\title{
Effect of Policy and Employee Capacity on the Provision of Quality Service among Private Security Firms for Mitigating Crime in Nairobi County in Kenya
}

\author{
*Otte Zebedee Ekwenye \\ Institute of Criminology, Forensic and Security Studies, DeKUT Kenya \\ P.O. Box 43844-00100 Nyeri, Kenya \\ Dr. Ruth Simiyu ${ }^{1} \quad$ Dr. Evans Oruta ${ }^{2}$ \\ 1.Department of Peace and Conflict Studies, Masinde Muliro University of Science and Technology \\ 2.Department of Criminology and Social Work (CSW), Masinde Muliro University of Science and Technology \\ P.O. Box 190-50100 Kakamega, Kenya
}

\begin{abstract}
This study assessed effect of policy and employee capacity on the provision of quality service among private security firms for mitigating crime in Nairobi County in Kenya. The specific objectives were to explore how policy and employee capacity affect the provision of quality service among PSFs for mitigating crime in Nairobi County in Kenya. The study was guided by SERVQUAL theory. This study used descriptive survey design with structured questionnaires as the instrument for data collection. The study targeted top managers, assistant managers and the immediate supervisors in 55 Private security firms registered under KISIA in Nairobi County. A census was used to sample the respondents of the study. The study employed drop and pick method to administer the questionnaires to the respondents. The study also conducted a pilot study on 10 respondents' to check for the reliability and validity of the research instrument. The respondents who partook in the pilot study were no included in the final study. The data was analyzed using SPSS version 21 to achieve the study results. Descriptive statistics was presented using; pie charts, frequency table, and graphs. Correlation and regression analysis results were presented using tables. Results of the study revealed that policy and employee capacity has a positive and significant influence on the provision of quality service for mitigating crime among the private security firms in in Nairobi County. The study established that the adoption of the right policies such as compliance with the KISIA regulations has a positive influence on the provision of quality security service by PSFS for mitigating crime in Nairobi County. The study also established that employee capacity positively and significantly influences the provision of quality security service for mitigating crime among PSFs in Nairobi County. The study recommends the Public Security Firms to ensure they comply with KISA regulations to allow for effective provision of standard quality of security. The study recommends the PSFs to put in place proper control structures to assess the suitability of their staff. PSFs should also adopt proper training methods with the current technical skills and knowledge, and interactive skills.
\end{abstract}

Key Terms: Policy, Employee Capacity, Quality Service, Crime Mitigation, Private Security Firms

DOI: $10.7176 /$ PPAR/11-6-03

Publication date:July $31^{\text {st }} 2021$

\section{Introduction}

Security has been vital to humanity since the ancient times and its importance cannot be over emphasized. Social, economic and political structures in every society are dependent on security systems they society adopts. Dempsey (2008) notes that, people have had the right to protect themselves against any threat since time immemorial. According to Fischer \& Green (2010), governments have limited resources and thus cannot provide one hundred percent security for its people hence a dire need for the Private Security Firms (PSF) to complement efforts of governments in crime mitigation. This argument is further supported by Ekhomu, (2010) who, further notes that there is no single government that has the capacity to provide one hundred percent security to its people. Additionally, Mayah (2011) argues that the need for private security firms may be because of citizen's fear of crime, and awareness that the public police cannot effectively control crime by themselves. Therefore, this mandates greater cooperation with the private sector and its resources to jointly forge a partnership for crime prevention and reduction.

The size and the role of the private security industry in crime mitigation have developed drastically all over the globe as of late. Expanded weight upon the law implementation officers have brought about numerous nations around the globe in the privatization of some police capacities, with the private security industry filling the crevices left by the overstretched police. Isenberg (2009) asserts that modern democratic countries like the United States, Britain and Canada reached a watershed in the evolution of their crime control and law enforcement in the 1960s. This is when the states monopoly on policing was broken with the creation of private 
and community based agencies to prevent crime, deter criminality, catch lawbreakers, investigate offences and stop conflict. According to Ruteere (2011), however, the concept of private security and community policing, largely popularized in the United States and in the United Kingdom from the 1980s onwards, was based on the principle of co-ordination and consultation between the police and the policed. It is also based on the definition of security needs and on the implementation of ways of preventing and curbing crimes and of enhancing safety. The success of security firms in the western word in crime mitigation has been attributed to the high level of quality service provision coupled with sophisticated technology. In these democracies, there are clearly laid down policies legislated structures that take into account aspects of individuals and organizations involved in the sector. Since the 1980s the British government has actively promoted the role of the private security industry within the criminal justice system. Peterson (2007) further notes that generalization of security provision has been given official recognition in England and Wales with the passing of the Private Security Act, 2001 which acknowledged the enhanced presence of commercial organizations in the provision of security and the Police Reform.

Gumedze (2008) notes that in sub-Saharan Africa, South Africa presents the most advanced experience in the implementation of private security to date. Private security in this country follows from a long experience in the townships of fear and hatred of the police during apartheid, together with a dependence on private security initiatives. Omotoso \& Aderinto (2016) notes that in Nigeria, like other parts of the world where private security firms have taken root, on the corporate industry and developed out of the population expansion have occurred without the capacity of the state actors to manage it hence questionable quality standards. These authors further note that in Nigeria most private security firms are faced with challenges such as little job satisfaction and few job commitments among the staffs alongside other operations challenges.

Consequently, in Kenya private security firms provide a varied of services from basic guarding to more sophisticated service of Very Important Person (VIP) protection and cash transit (Safer World, 2008). Wairagu (2014) further adds that private security firms offer a range of services including; classical physical protection of private and public properties, close protection of VIP's, cash-in-transit escort, safeguarding 'properties of strategic importance' and security for sports and music events. The private security sector therefore is a vibrant reality here in Kenya with presence of international private security firms such as G4S, Well Fargo among others. Wairagu additionally observes that, private security industry fill the gap that the Government of Kenya (GoK) may be unable to bridge using its conventional security architecture, which typically includes policing, military, paramilitary, national youth service and intelligence services

The private security industry in Kenya is spread across the country, although it is much more visible in urban center's than it is in rural areas hence its impact on job creation is more felt in the urban areas particularly within Nairobi, Kisumu, Mombasa, Eldoret, Nakuru and in many other growing town centers. It is estimated that over 2.4 million Kenyan are employed in the private security sector. The Kenya Vision 2030 and the MediumTerm Plan (2008-2012) recognizes security as the foundation of good governance, societal welfare and economic development. Mkutu \& Sabala (2010) further note that the government has made a substantive push towards strengthening the security sector to assist in security service provision due to heightened security concerns in the aftermath of recent terror attacks.

The reviewed literature concurs on the importance of quality service provision by private security firms in crime mitigation. The literature also concentrates much on the gap that private security firms fill in the void left by the government security agencies, However much of this literature fails to capture the contribution of the various drivers of quality service provision by private security firms in crime mitigation, hence a gap exists that this research attempted to fill.

\section{Statement of the Problem}

Despite Kenya adopting the Private Security Regulatory Act of 2016, many small security companies continue to operate unregulated hence offering poor quality services. Many of these companies pay little attention to service standards and mostly the small privately owned security firms, which are not registered with Kenya Security Industrial Association and continue to operate illegally. To bridge the gap, Kenya Security Industrial Association (KISIA) was formed by companies in need to comply with the set standards drawn from the Laws of Kenya and internationally accepted technical and systems specifications. To establish a set of benchmarks however only less than $30 \%$ of the private security firms have registered with Kenya Security Industrial Association. The past decade has seen new crime and violence trends in Kenya; terrorist, militia and gang activities, which include mugging, raping and killing of innocent citizens, and the apparent failure of state security agents including private security firms, against criminals is a sign of poor strategic management of crime and violence. The causes of crime are often linked to institutional weaknesses of society. The wake of continuous growth of crime in Nairobi County has brought with it unprecedented challenges for PSFs in the recent past. In as much as resolving the underlying causes of crime not being a domain of private security companies their existence is in security provision for the contracting clients Private Security Firms plays a 
pivotal role in crime mitigation. To achieve the goal of adequate and reliable security provision PSFs need to improve on the quality of service they provide to their client.

This study evaluated the drivers of quality service provision particularly those touching on standards, may include, and not limited to policy, employee capacity, technology adoption and partnership of state agencies among private security firms in the aim of mitigating crime. The study therefore brought out the key drivers that Private Security Firms could adopt in improving their service delivery hence quality service provision in their endeavor to mitigate crime.

\section{Objectives of the Study General Objective}

The general objective of this study was to assess the effect of policy and employee capacity on the provision of quality service among private security firms for mitigating crime in Nairobi County in Kenya

\section{Specific Objectives}

This study was guided by the following specific objectives; i. security firms in Nairobi county Kenya.

To explore the effect of policy on mitigating crime by private ii. To assess the effect of employee capacity on mitigating crime by private security firms in Nairobi County Kenya.

\section{Significance of the Study}

The results of this research were significant in many organizations that have been looking for solutions in crime mitigation. While past studies have not investigated drivers of service quality in mitigating crime this research was done in the backdrop of a phenomenal escalation of crime. It is a reality that public and private agent involved in security management do not have clearly defined avenues to counter the growing menace, this research attempted to increase awareness on how to improve operational efficiency of existing private security management with the sole aim of fighting crime menace in Nairobi County. Based on findings of this research as background, it was possible to conduct in depth studies to point out the needed changes in the strategy to counter crime growth. Every government has an obligation to provide security to its people. This study was geared toward looking at what can enhance the quality of security services provided. From the finding of this study security firms was able to conduct in depth studies to point needed changes in strategy to counter crime growth, hence this complemented the government effort in fight against crime. Attainment Kenya vision 2030 requires partnership and collaboration with an effective and efficient private sector team. Provision of quality services among private security firms is a greater pillar towards attainment of this vision. This study therefore was significant to both economic and social pillar of the Kenya vision 2030. In terms of managerial practice in the sector, this study hoped to bring to light how quality service provision and helped in addressing growing crime. This knowledge was useful to the industry associations in the creation of frameworks to guide member security firms. The finding of the research was also add a significant body of knowledge to the public on what to evaluate when sourcing for private security firms to provide security service for their lives and property. The findings also added significant body of knowledge to the scholarly world of security management.

\section{Theoretical Review}

Theoretical review helps the researcher to make assumptions on the existing association between the study variables, which are vital in developing the research questions that directs the research. This study was anchored on SERVQUAL Theory. Van Looy, Gemmel and Dierdonck (2003) asserted that quality holds the key to competing in today's global market by assisting in clear development of marketing strategies by building strong brand names. Despite the fact that quality management practices are primarily embraced in the manufacturing sector, quality management in the service industries has been gaining momentum over the past decade through Total Quality Management (TQM). The main theoretical framework by Zeithaml et al., (1988) is a SERVQUAL theory (Figure 1). It is relevant to this research study, as private security service requires high consumer involvement in the consumption process; hence, the attainment of quality service relies significantly on the cocontribution of the employees to the service delivery process. 


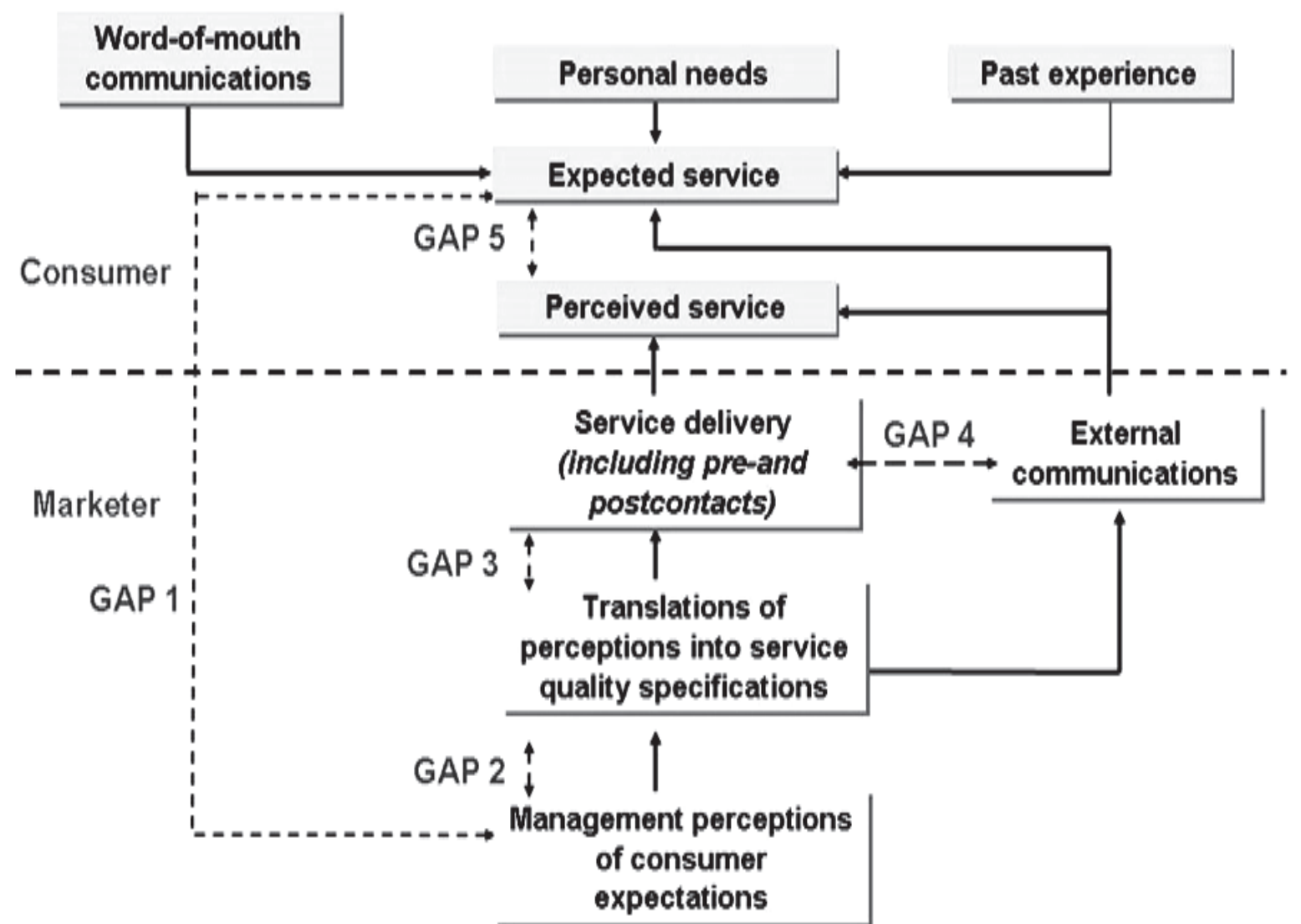

Figure 1 Zeithaml et al (1988) Extended Service Model Employee Capacity

The various drivers of quality service provision enable service providers such Private Security Firms address the various service gaps that might exist. Zeithmal, (1988), highlights that service quality is achieved when, all the service quality gaps are addresses as detailed by the model illustrated in Figure 1 above. This model therefore forms a fundamental foundation of this study by affirming the fact that PSFs like other service organizations need to close any gap that affects negatively on quality of the service they provide to their clients.

\section{Empirical Review}

\section{Policy and Crime Mitigation}

Private security policy affects the manner at which crime mitigation is affected. When the policy is poor, it means the result of crime mitigation will be low as well. In respect to the Government support, government input helps a lot in promoting and coordinating the entire operation of the organization to ensure service provision meats the threshold of crime mitigation. Moreover, regulations such as industrial regulation procedure and code of conduct can a great effect on the quality of service provision by the private firms to ensuring crime mitigation this is coupled with the level of Security management the company has adopted and structured to ensure their security plans is inclined to achieving crime mitigation.

In a report containing findings of a fact-finding team convened by UNI Property Services to investigate labour practices at Secure Force Security in Malawi, Mozambique, and South Africa in April 2007, Ritchie et al (2007) found serious and ongoing violations of labour laws. Many of these concerned overtime and time-off as well as behaviour that have consigned workers to a hand-to-mouth existence. The team concluded that Secure Force Security should ensure its operations across the globe abide by local laws, provide workers with living wages and family sustaining benefits, and allow workers who want to organize unions to do so. Further, it concluded that the best way for Secure Force Security to demonstrate it is worthy of trust is to sign a global agreement with UNI Global Union in which it commits to pay a living wage - adequate to sustain his/her family. It was also to provide social protections, and recognize workers freedom to form unions.

Russell (2010) further notes that every private security firm needs effective crime prevention policy, which will remain relevant as new crime emerges. According to Russel working with the police agencies and other key partners in the security sector are some of the policies that should be enhanced by private security firms. The arguments posed by the various scholars in relation to policies in the realm of private security firms and crime mitigation has been appreciated. Authors have a consensus that good policies are key to quality service provision. However, the Russell (2010) has not clearly demonstrated the impact of policies in quality service provision; this 
research therefore sought to fill this gap.

\section{Employee Capacity and Crime Mitigation}

Security level of education directly affects the professionalism of security guards in their service delivery hence determining to whether they will be able to mitigate crime in line with the organization's objective. To achieve this, it means on job training and interactive skills of security guards as a factor within the employee capacity need to be improved to enhance crime mitigation.

Tornow and Wiley (2010) found a positive correlation between the capacity of employees and the provision of quality service. They also found that customer satisfaction is directly related to the attitude and perceptions of employees, which relates to the organization and its management practices. To improve effectiveness in service quality, organizations must build the capacity to retain, attract and employ an adequate number of high-quality employees' in order to adapt to circumstances that are constantly changing.

According to a study by Schneider; Russell Beasty \& Baird (2011), to provide high quality service, employees need to get enough training in the necessary technical skills and knowledge, and interactive skills. Interactive skills help employees to provide courteous, caring, responsive and empathetic service. Successful Firms invest heavily in training and make sure that the training fits their business goals and strategies. Many security guards are required to go through additional training mandated by the state for the carrying of weapons such as batons, firearms, and pepper spray. Some guards are required to complete police certification for special duties. For security and police, training standards are identical with regards to firearms but do not place any formal requirements for other items carried, however training be provided should be documented. A number of security companies have become certified in giving training for use of Surveillance Radars and training their officers to use them on protected properties in conjunction with lights/sirens, permitting them to legally implement traffic laws on private assets. Enhanced employee capacity has been cited as key toward quality service provision, however there lacks a consensus among the cited security scholars on the extent that employee capacity contributes to crime mitigation. This research therefore wished to establish the contribution of employee capacity to crime mitigation.

\section{Conceptual Framework}

The conceptual framework below highlights both the independent and the dependent variables. The framework indicates how the researcher analyzed the relationship between the independent variables (Policy and Employee Capacity) and the dependent variable affect crime mitigation (Dependent variable) among private security firms in Nairobi County in Kenya. The various parameters that were used to measure each variable have been presented in Figure 2 below.

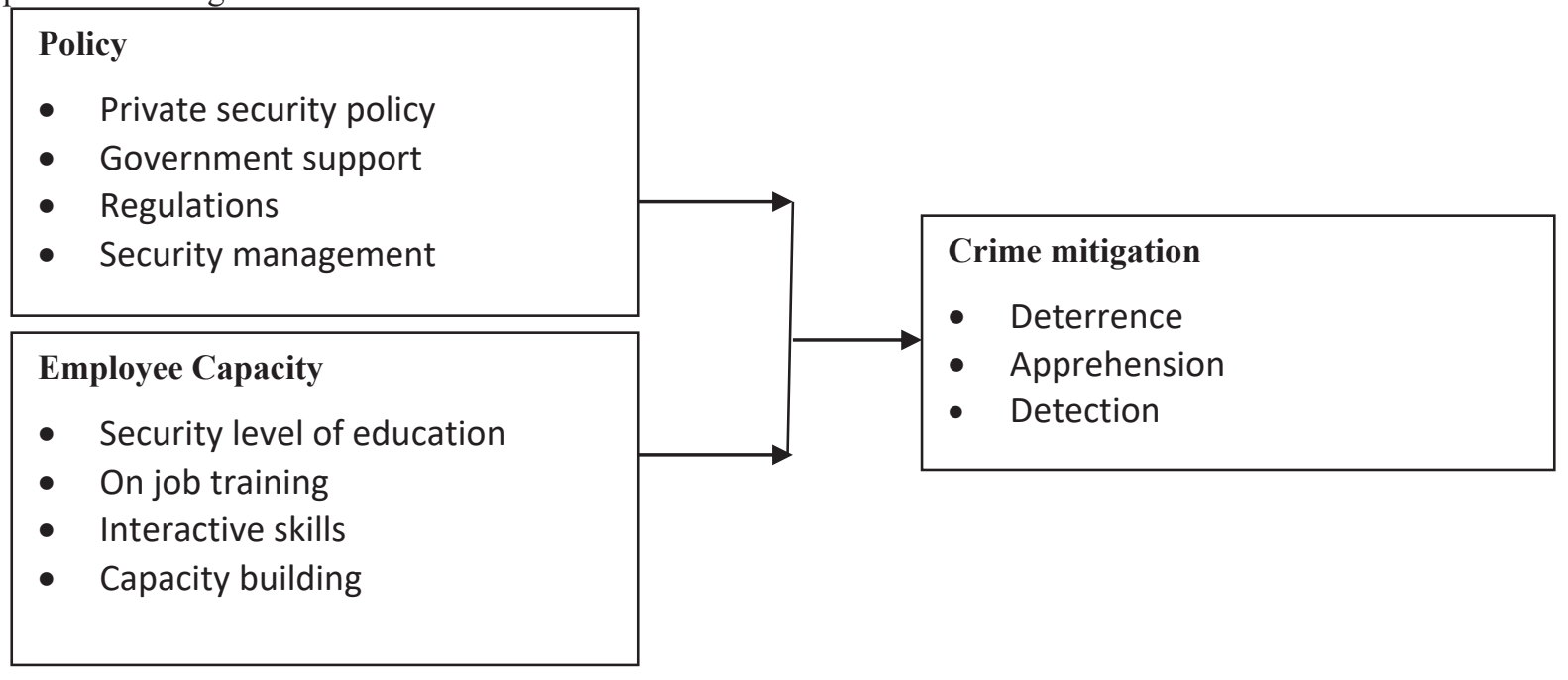

Independent Variables

\section{Dependent Variable}

\section{Fig 2 Conceptual Framework}

\section{Research Methodology}

This study employed a descriptive survey design with both quantitative and qualitative approaches. The target population for this study comprised of all private security firms in Nairobi who are members of KSIA. The target population for the study comprised of 55 Private security Firms registered with KSIA (2017) and have their presence in Nairobi. The study adopted a census approach and all the 55 PSFs formed the sample size for the 
study. The study used structured questionnaires to collect primary data. A self-administered questionnaire was issued for data collection. The research instruments were distributed to the selected private security firms. Before the actual field study commenced, the study pilot tested the research instrument to ensure its validity and reliability in answering the research problem. The study employed a sample of 10 respondents during the pilot study. The respondents who participated in the pilot study were not included in the actual study. Since the collected data quantitative in nature, they were analyzed using SPSS version 21 to generate frequency tables, percentages and graphs as descriptive statistics. Inferential statistics were computed using a multiple linear regression model to show the relationship between the drivers and market and sales operation. Thus, a multiple regression used to model the results as depicted by the nexus between independent variables and the dependent variables is as indicated below;

$\mathrm{Y}=\beta 0+\beta_{1} \mathrm{X}_{1}+\beta_{2} \mathrm{X}_{2}+\beta_{3} \mathrm{X}_{3}+\beta_{4} \mathrm{X}_{4}+\epsilon$

Where: $\mathbf{Y}$ is the Crime mitigation, $\boldsymbol{B}_{\mathbf{0}}$ is the intercept or constant, $\boldsymbol{B}_{1}$ and $\boldsymbol{B}_{2}$, are regression coefficients for variables $\mathrm{X}_{1}=$ policy, $\mathrm{X} 2=$ employee capacity and $\epsilon=$ error term.

\section{Analysis Findings and Discussions}

The study administered 55 questionnaires to the top management, assistant managers and the immediate supervisors of security firms registered under KISIA. Forty-eight out of the 55 questionnaires were duly filled and returned. This translates to $87.27 \%$ response rate, which is an acceptable response rate in social research. The findings are in agreement with the assertion of Mugenda and Mugenda (2003) who affirmed that a return rate of $50 \%$ is considered acceptable for a descriptive research to analyze and publish, $60 \%$ are good and $70 \%$ are very good. Hence, a return rate $87.27 \%$ was considered adequate this study.

\section{Effect of Policy on Crime Mitigation among Private Security Firms}

The study sought to determine the effect of polity in crime mitigation among private security firms in Nairobi County. The results revealed that majority of the participants (63\%) strongly agreed that clearly laid down private security policy enhance crime mitigation. Moreover, the findings showed that $63 \%$ of the respondents indicated that they strongly agree that government support have contributed to quality service provision by private security firms. Equally, 63\% of the participants indicated that they strongly agree that government oversight body to regulate the private security industry may come up with policy to enhance standards in the activities of security provision. Lastly, results revealed that majority $(63 \%)$ of the participants indicated that they strongly agree that security management policy that involves public and private agents may lead to provision of quality security service.

\section{Table 1 Descriptive Statistics of Policy}

\begin{tabular}{|c|c|c|c|c|c|c|}
\hline Statements & $\begin{array}{l}\text { Strongl } \\
\text { y agree } \\
(\%)\end{array}$ & $\begin{array}{l}\text { Agr } \\
\text { ee } \\
(\%)\end{array}$ & $\begin{array}{l}\text { Neu } \\
\text { tral } \\
(\%)\end{array}$ & $\begin{array}{l}\text { Disa } \\
\text { gree } \\
(\%)\end{array}$ & $\begin{array}{l}\text { Strongly } \\
\text { Disagree } \\
(\%)\end{array}$ & $\begin{array}{l}\text { Tot } \\
\text { al } \\
(\% \\
)\end{array}$ \\
\hline $\begin{array}{l}\text { Clearly laid down private security policy enhance crime } \\
\text { mitigation }\end{array}$ & 63 & 27 & 0 & 3 & 5 & 100 \\
\hline $\begin{array}{l}\text { Government support have contributed to quality service } \\
\text { provision by private security firms }\end{array}$ & 63 & 3 & 5 & 0 & 27 & 100 \\
\hline $\begin{array}{l}\text { Government oversight body to regulate the private security } \\
\text { industry may come up with policy to enhance standards in } \\
\text { the activities of security provision }\end{array}$ & 63 & 27 & 0 & 3 & 5 & 100 \\
\hline $\begin{array}{l}\text { Security management policy that involve public and private } \\
\text { agents may lead to provision of quality security service }\end{array}$ & 3 & 5 & 27 & 63 & 0 & 100 \\
\hline
\end{tabular}

The study also asked the respondents to indicate the extent to which policy issues contribute to crime mitigation in their firm. The results are as shown in Table 2 below.

Table 2 Extent to Which Policy Issues Contribute to Crime Mitigation

\begin{tabular}{lll}
\hline Extent & Frequency & Percentage \\
\hline Very High & 35 & 64 \\
High & 3 & 5 \\
Moderate & 2 & 4 \\
Low & 15 & 27 \\
Total & $\mathbf{5 5}$ & $\mathbf{1 0 0 \%}$ \\
\hline
\end{tabular}

The findings in Table 2 above shows the majority 64\% of the respondents indicated that policy issues contribute to the crime mitigation to a very high extent. Those who indicated that policy issues contribute to the crime mitigation to a high extent were $5 \%$ while those who indicated that the effect of policy issues in crime mitigation is moderate were $4 \%$. Finally, the findings revealed that $27 \%$ of the participants indicated that policy 
issues contribute to crime mitigation to low extent.

\section{Effect of Employee Capacity on Crime Mitigating among Private Security Firms}

The study sought to determine the effect of employee capacity in crime mitigation among private security firms in Nairobi County. The results revealed that majority of the participants (73\%) strongly agreed that security level of education leads to effectiveness in security service quality. Moreover, the findings showed that $18 \%$ of the respondents indicated that they strongly agree that on job training to effectiveness in security service quality. Similarly, $73 \%$ of the participants indicated that they strongly agree that interactive skills enable security to provide high quality service. Finally, results revealed that majority (73\%) of the participants indicated that they strongly agree that capacity building leads to provision of quality security service. Descriptive results are as shown in table 3 below.

Table 3 Descriptive Statistics of Employee Capacity

\begin{tabular}{|c|c|c|c|c|c|c|}
\hline 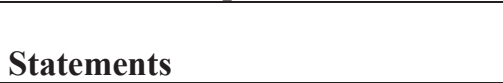 & $\begin{array}{l}\text { Strongly } \\
\text { agree }(\%)\end{array}$ & $\begin{array}{l}\text { Agree } \\
(\%)\end{array}$ & $\begin{array}{l}\text { Neutral } \\
(\%)\end{array}$ & $\begin{array}{l}\text { Disagree } \\
(\%)\end{array}$ & $\begin{array}{l}\text { Strongly } \\
\text { disagree }(\%)\end{array}$ & $\begin{array}{l}\text { Total } \\
(\%)\end{array}$ \\
\hline \multicolumn{7}{|l|}{$\begin{array}{l}\text { Security level of education leads } \\
\text { to effectiveness in security service }\end{array}$} \\
\hline On job training to effectiveness in & 18 & 2 & 73 & 2 & 5 & 100 \\
\hline provide high quality service & 73 & 18 & 2 & 2 & 5 & 100 \\
\hline $\begin{array}{l}\text { Capacity building leads to quality } \\
\text { security service provision }\end{array}$ & 73 & 18 & 2 & 2 & 5 & 100 \\
\hline \multicolumn{7}{|c|}{$\begin{array}{l}\text { The study also asked the respondents to indicate the adequacy of the training provided to them after } \\
\text { recruitment. The results are as shown in table } 4 \text { below. } \\
\text { Table } 4 \text { Adequacy of the Training Offered to the Officers after Recruitment AT PSFs }\end{array}$} \\
\hline Extent & Frequency & & & Percentag & & \\
\hline Very adequate & 10 & & & 18 & & \\
\hline Adequate & 40 & & & 73 & & \\
\hline Fair & 3 & & & 5 & & \\
\hline Inadequate & 1 & & & 2 & & \\
\hline Poor & 1 & & & 2 & & \\
\hline Total & 55 & & & 100 & & \\
\hline
\end{tabular}

The findings in Table 4 above indicates that $18 \%$ of the respondents indicated that the training offered to them after recruitment was very adequate while majority of them indicated that the amount of training they receive after recruitment is adequate. Moreover, the findings shows that $5 \%$ of the respondents indicated that the training offered to them after recruitment is fair while $2 \%$ of them indicated inadequate and poor respectively.

Bivariate Correlation Results between Crime Mitigation and Strategies Adopted

The findings in Table 5 below shows that there is a positive and significant correlation between the strategies adopted by the private security firms and crime mitigation in Nairobi County as indicated by a Pearson correlation coefficient of 0.596 and significance value of 0.002 . This implies that the strategies adopted influence crime mitigation.

Table 5 Bivariate Correlation

\begin{tabular}{lll}
\hline Correlation $(\mathbf{r})$ & $\mathbf{N}$ & Significance \\
\hline 0.596 & 55 & 0.002 \\
\hline
\end{tabular}

Combined Effect of Policy and Employee Capacity on Crime Mitigation

A regression model was used to evaluate the effect of policy and employee capacity on crime mitigation. The model summary findings are as shown in Table 6 below.

Table 6 Model Summary

\begin{tabular}{lrrcc}
\hline Model & R & R square & Adjusted R Square & Std. Error of the Estimate \\
\hline 1 & 0.882 & 0.777 & 0.754 & 0.102 \\
\hline
\end{tabular}

The model summary results also shows that policy and employee capacity accounts for $77.7 \%$ of the variation in crime mitigation in Nairobi County. This is indicated by an R-square value of 0.777 . The regression results show that $\mathrm{R}$ was 0.882 which shows that the relationship between the independent variables ((policy and employee capacity) and the dependent variable (crime mitigation) was positive. 
Table 7 ANOVA Results

\begin{tabular}{lllllll}
\hline Model & & Sum of Squares & df & Mean Square & F & Sig. \\
\hline 1 & Regression & 2.56 & 4 & 0.211 & 3.98 & $.023 b$ \\
& Residual & 0.634 & 44 & 0.053 & & \\
& Total & 3.914 & 48 & & & \\
\hline
\end{tabular}

a Dependent Variable: Crime Mitigation

b Predictors: (Constant), Policy, Employee Capacity

ANOVA results in Table 7 above shows that the overall regression model linking policy, employee capacity and crime mitigation in Nairobi County was significant as indicated by a significant F $(4,44)$ statistic as indicated by (0.023) significance level which was less than 0.05 at $5 \%$ level of significance. $\mathrm{F}$ calculated is 3.98 while $\mathrm{F}$ critical is 2.583 . F calculated is greater than the F critical $(3.98>2.583)$; this indicated that the overall model was statistically significant at 5\% significance level.

Table 8 Regression Coefficients

\begin{tabular}{llllll}
\hline Model & \multicolumn{2}{l}{ Unstandardized Coefficients } & Standardized Coefficients & t & Sig. \\
\hline & $\mathrm{B}$ & Std. Error & Beta & & \\
\cline { 2 - 6 } (Constant) & 2.342 & 0.233 & & 10.05 & 0.013 \\
Policy & 1.456 & 0.512 & 1.418 & 2.840 & 0.041 \\
Employee capacity & 1.563 & 0.614 & 2.177 & 2.545 & 0.000 \\
\hline
\end{tabular}

The optimal regression model thus is as shown below;

Crime Mitigation $=\mathbf{2 . 3 4 2}+\mathbf{1 . 4 5 6}$ Policy $+\mathbf{1 . 5 6 3}$ Employee Capacity $+\varepsilon$

The summary of the results of regression coefficients are as presented in Table 8 above. Results of the study reveal that policy has a positive and significant influence on the quality of service for mitigating crime among PSFs in Nairobi County $(\beta=1.456$, Sig $=0.41)$. This implies that proper oversighting and regulation by KISA as well as proper control of personnel by the private security firms leads to 1.456 unit increase in crime mitigation in Nairobi County. Moreover, the results of the study revealed that employee capacity had a positive and significant effect on the provision of quality service for crime mitigation among PSFs in Nairobi County ( $\beta=$ 1.563 , Sig $=0.000)$. This implies that an improvement in the employee capacity to handle security threats, more training with regard to the interactive skills of security guards with clients in a professional way leads to 1.563 unit increase in crime mitigation in Nairobi County.

\section{Conclusions}

The study established that the adoption of the right policies such as compliance with the KISA regulations such as continuous oversighting has a positive influence on the provision of quality security service by PSFS for mitigating crime in Nairobi County. The study also established that Employee Capacity positively and significantly influences the provision of quality security service by PSFs in Nairobi County. More training of staff to improve their ability to interact effectively, detection and response skills influences the quality of security service by PSFS for mitigating crime in Nairobi.

\section{Recommendations}

The study recommends the Public Security Firms to ensure they comply with KISA regulations to allow for effective provision of standard quality of security. The study recommends the PSFs to put in place proper control structures to assess the suitability of their staff. The study recommends the PSFs to partner with police agencies as well as other key stakeholders in the security sector in Kenya in order to broaden their service delivery. The study also recommends the PSFs to build staff capacity so as to retain, attract and employ an adequate number of high-skilled employees' in order to adapt to circumstances that are constantly changing in the security sector. PSFs should also adopt proper training methods with the current technical skills and knowledge, and interactive skills.

\section{References}

Dempsey, J. S. (2008), “Introduction to private security”, Belmont: Thomson Higher Education.

Ekhomu, O. (2004) Outsourcing non-core Police functions to private security Firms

Fischer, R.J. and Green, G. (2004). Introduction to Security 7th Edition. Burlington: Butterworth Heinemann.

Gumedze, S. (2008). The private security sector in Africa: Country series. Institute for Security Studies Monographs, 2008(146), 106.

Isenberg, D. (2009). Private military contractors and US grand strategy. International Peace Research Institute (PRIO

Kenya Security Industrial Association, KSIA. (2016). Code of conduct. Retrieved August 9, 2014, from Kenya Security Industrial Association: http://www.ksia.co.ke/code-of-conduct.htm.

Van Looy, B., Gemmel, P., \& Dierdonck, R. (Eds.). (2003). Services management: An integrated approach. 
Pearson Education.

Mayah, E.O. (2003). Walking the narrow road. Industrial security in Nigeria

Mkutu, K. Sabala (2007) Private Security Firms in Kenya and Dilemmas for Security, Journal for Contemporary African Studies"

Mugenda and Olive Mugenda: (2003) Research methods; Qualitative and quantitave approach in Nairobi Acts

Omotoso, O., \& Aderinto, A. A. (2016). Challenges of Providing Security in Lagos State: The Case of Corporate Private Security Organizations. African Journal of Criminology and Justice Studies: AJCJS, 9(1), 1

Paterson, C. (2007). Commercial crime control and the electronic monitoring of offenders in England and Wales. Social Justice, 34(3/4 (109-110), 98-110Porter?

Richie et al (2007): Who Protects the Guards? The Facts Behind Secure Force Security in Southern African: Findings of a Global Fact-Finding Team May 2007. UNI Property Services Alliance for Justice at Secure Force Security

Ruteere, M. (2011). More than political tools: The police and post-election violence in Kenya. African Security Review, 20(4), 11-20.

Safer World (2008), “Implementing Community Poling in Kenya”, Nairobi, Kenya. February 2008.

Schneider C. E., Russell C. J., Beatty W. \& Baird L. S. (2003).The training and development USA: HRD Press. Thuranira

Tornow W. \& Wiley J. (2010). Service quality and management practices: a look at employee attitude, customer satisfaction, and bottom-line consequence. Hum. Resource Plan. 14(2):105-115

Wairagu F. Kimenju J. Singo M., (2004). Private Security in Kenya. Security research and information centre (SRIC), Nairobi.

Zeithaml, V. (2006). Customer metrics and their impact on financial performance. Marketing 